\title{
Bacterial Counts in Organic Materials Used as Free-Stall Bedding Following Treatment with a Commercial Conditioner ${ }^{1}$
}

\author{
J. S. Hogan, ${ }^{1}$ S. L. Wolf, and C. S. Petersson-Wolfe \\ Department of Animal Sciences, The Ohio State University, Ohio Agricultural Research and Development Center, Wooster 44691
}

\begin{abstract}
An acidic conditioner was tested in recycled manure and sawdust used as free-stall bedding to determine the effect on bacterial counts of common environmental mastitis pathogens. Free stalls were bedded with $10 \mathrm{~kg}$ of either kiln-dried sawdust or recycled manure per stall. All bedding was removed and fresh bedding was applied every $7 \mathrm{~d}$. Approximately $1 \mathrm{~kg}$ of commercial bedding conditioner containing $93 \%$ sodium hydrosulfate (wt/wt) was spread evenly over bedding in the back one-third of each treated stall. Control bedding received no treatment. Cows were bedded on the same material for 3 consecutive weeks. After $3 \mathrm{wk}$ on a bedding treatment, cows remained in the same pens and bedding treatments were changed between rows within pens in a switch-back design. The addition of bedding conditioner to sawdust reduced gram-negative bacterial, coliform, Klebsiella spp., and streptococcal counts immediately after application and $1 \mathrm{~d}$ after application. Bacterial counts did not differ between treated and untreated sawdust on $d 2$ and 6 after the conditioner treatment. Each bacterial count measured was reduced in recycled manure immediately after application. Gram-negative bacterial and streptococcal counts were reduced in treated recycled manure compared with untreated recycled manure on $\mathrm{d} 1$ after conditioner was applied. Bacterial counts did not differ between treated and untreated recycled manure bedding on $\mathrm{d} 2$ and 6 after application in free stalls. The antibacterial activity of the conditioner was related to the $\mathrm{pH}$ of the bedding and was diminished by d 2 after application in both bedding types.
\end{abstract}

Key words: bedding, bacterial count

\section{INTRODUCTION}

Bacterial populations in materials used as bedding in stalls for lactating cows have been correlated with teat end exposure to mastitis pathogens (Rendos et al.,

Received July 14, 2006.

Accepted October 10, 2006.

${ }^{1}$ Corresponding author: hogan.4@osu.edu
1975; Fairchild et al., 1982) and rates of clinical mastitis (Hogan et al., 1989). The bacterial populations differ greatly among materials commonly used to bed free stalls (Hogan et al., 1989). The differences among the bedding materials for sustaining bacterial populations have been related to particle size, $\mathrm{DM}, \mathrm{pH}$, and environmental factors (Fairchild et al., 1982; Ward et al., 2002). Adding chemical disinfectants to organic bedding materials significantly reduced populations of bacteria for 1 $\mathrm{d}$ after application in bedding treated with conditioners and on the teat ends of cows housed in stalls. The antibacterial effects of disinfectants were greatly diminished, and mastitis pathogen populations were comparable between treated cows and bedding and untreated controls on d 2 and 6 after disinfectant application (Hogan and Smith, 1997; Hogan et al., 1999). The antibacterial activities of disinfectants were related to the $\mathrm{pH}$ of the bedding (Hogan et al., 1999). Alkaline-based products controlled bacterial populations more effectively in recycled manure (approximately $\mathrm{pH}$ 6.0) than in kilndried sawdust (approximately pH 4.0). Conversely, an acidic product was more effective in kiln-dried sawdust than in recycled manure.

The use of chemical treatments to repress mastitis pathogens in organic bedding materials may be a plausible management practice for reducing mastitis if the disinfectants can maintain antibacterial activity in the free-stall environment. The purpose of the current trial was to test the antibacterial persistency of an acidic conditioner in free stalls bedded with either recycled manure or kiln-dried sawdust.

\section{MATERIALS AND METHODS}

\section{Experimental Design}

The experiment was conducted at the Ohio Agricultural Research and Development Center (Wooster, $\mathrm{OH}$ ) during July and August of 2005. Kiln-dried sawdust and recycled manure bedding were tested in a sideopen free-stall barn housing lactating cows. Each pen consisted of 2 rows of free stalls separated by a 3.05-m alley. The alley was scraped 8 times per day during the study by manual control of a mechanical scraper. Stalls were separated from feed and water by a $2.13-\mathrm{m}$-wide 
alley and a solid board partition measuring $1.22 \mathrm{~m}$ in height. Stalls were separated from the exterior sideopen walls of the barn by a $1.22-\mathrm{m}$-tall board partition and a 1.5-m cow transport alley. Sawdust and recycled manure were stored separately in covered sheds and were not composted before use as bedding. Recycled manure was recovered solids (FAN PSS; Fan Separator, Inc., Michigan City, IN) from the trial herd. Each stall was a $170 \times 150 \mathrm{~cm}$ concrete base with cushioned mats. One pen of 16 free stalls was bedded with $10 \mathrm{~kg}$ of kilndried sawdust per stall. Another pen of 16 free stalls was bedded with $10 \mathrm{~kg}$ of recycled manure solids per stall. One row of 8 stalls in both pens received either 1) addition of approximately $1 \mathrm{~kg}$ of commercial bedding conditioner containing 93\% sodium hydrosulfate (wt/ wt; Parlor Pal; Jones-Hamilton Co., Walbridge, $\mathrm{OH}$ ) spread evenly over sawdust in the back one-third of each stall on the days that stalls were cleaned and covered with fresh bedding, or 2) control bedding with no treatment. Cows were bedded on the same material for 3 consecutive weeks, and every $7 \mathrm{~d}$ all bedding was removed and fresh bedding was applied. Stalls were cleared of wet bedding and manure twice daily. Cows remained in the free-stall pens continuously except for approximately $1 \mathrm{~h}$ each day during milking. After $3 \mathrm{wk}$ on a bedding treatment, cows remained in the same pens and bedding treatments were changed between rows within pens. The trial lasted 6 wk so that cows were exposed to both bedding treatments in a switchback design.

\section{Bedding Samples}

Samples were collected immediately after either fresh bedding or bedding plus conditioner was added to stalls (d 0 ) and 1, 2, and $6 \mathrm{~d}$ later. Composite bedding samples were collected from 4 of the 8 stalls in each bedding treatment group. A composite bedding sample was 3 subsamples (approximately $30 \mathrm{~g}$ per subsample) of bedding collected from preselected sites in the back one-third of a stall. Composite samples from each stall were placed in sterile bags, thoroughly mixed in the bags, and analyzed separately ( 16 bedding samples analyzed per sample day). Twenty-five grams of each sample was placed in a convection oven at $100^{\circ} \mathrm{C}$ for $24 \mathrm{~h}$ to determine the DM content. A total of $10 \mathrm{~g}$ of bedding was suspended in $90 \mathrm{~mL}$ of sterile distilled water, and the $\mathrm{pH}$ of the aqueous solution was measured electronically (Corning $\mathrm{pH}$ meter 430; Corning Life Sciences, Corning, NY). Bacterial populations in a bedding were enumerated by adding $10 \mathrm{~g}$ of sample to $90 \mathrm{~mL}$ of sterile PBS ( $\mathrm{pH} 7.2$ ) and mixing the solution for $40 \mathrm{~s}$ in a stomacher (Stomacher Lab-Blender 400; Tekmar Co., Cincinnati, OH). Serial dilutions of the liquid phase in sterile PBS were plated on the surface of MacConkey agar (Becton Dickinson Microbiology Systems, Cockeysville, MD), MacConkey-inositol-carbenicillin agar (MCIC), and modified Edwards agar containing $5 \mathrm{mg} /$ $\mathrm{L}$ of colistin sulfate and $2.5 \mathrm{mg} / \mathrm{L}$ of oxolinic acid (Becton Dickinson Microbiology Systems). Inositol (10 mg/L; Sigma Chemical Co., St. Louis, MO) and carbenicillin (75 mg/L; Pfizer Co., New York, NY) were added to the MacConkey agar for the MCIC. Bovine plasma $(50 \mathrm{~mL} /$ L) was substituted for whole blood to prepare the modified Edwards media. Serial dilutions plated on all media were $1: 10^{2}$ to $1: 10^{6}$. Inoculated plates were incubated for $24 \mathrm{~h}$ at $37^{\circ} \mathrm{C}$. Colony forming units per gram were identified as gram-negative bacteria (total growth on McConkey agar), coliforms (lactose-positive colonies on MacConkey agar), Klebsiella spp. (pink to red colonies on MCIC), and streptococci (total growth on modified Edwards agar). Bacterial counts were expressed as $\log _{10}$ per gram of bedding.

\section{Statistical Analyses}

Bacterial counts, DM, and $\mathrm{pH}$ were analyzed by least squares ANOVA using the mixed procedure of SAS (SAS Institute, 2003). The main effects for each variable were treatment, bedding, row of the free stall within a pen, day of the week, period, and week of the period. Main effects and possible 2-way interactions were tested. Differences among treatment $\times$ day means within a variable were tested by Tukey's multiple comparisons procedure. Significance was defined as $P<$ 0.05 .

\section{RESULTS}

\section{Sawdust}

The addition of bedding conditioner to sawdust bedding reduced the gram-negative bacterial, coliform, Klebsiella spp., and streptococcal counts immediately after and d 1 after application (Figure 1). Bacterial counts did not differ between the sawdust bedding treatment groups on $d 2$ and 6 after application. Sawdust treated with conditioner had a reduced $\mathrm{pH}$ on $\mathrm{d} 0$, 1 , and 2 compared with untreated bedding. Treatment with conditioner did not affect the DM content of sawdust.

\section{Recycled Manure}

Recycled manure treated with conditioner had lower gram-negative bacterial and streptococcal counts than did untreated recycled manure on $\mathrm{d} 0$ and 1 (Figure 2). Coliform and Klebsiella spp. counts were reduced by addition of the conditioner on $d 0$, but not on $d 1$. None 


\section{Control}

$\square$ Treatment
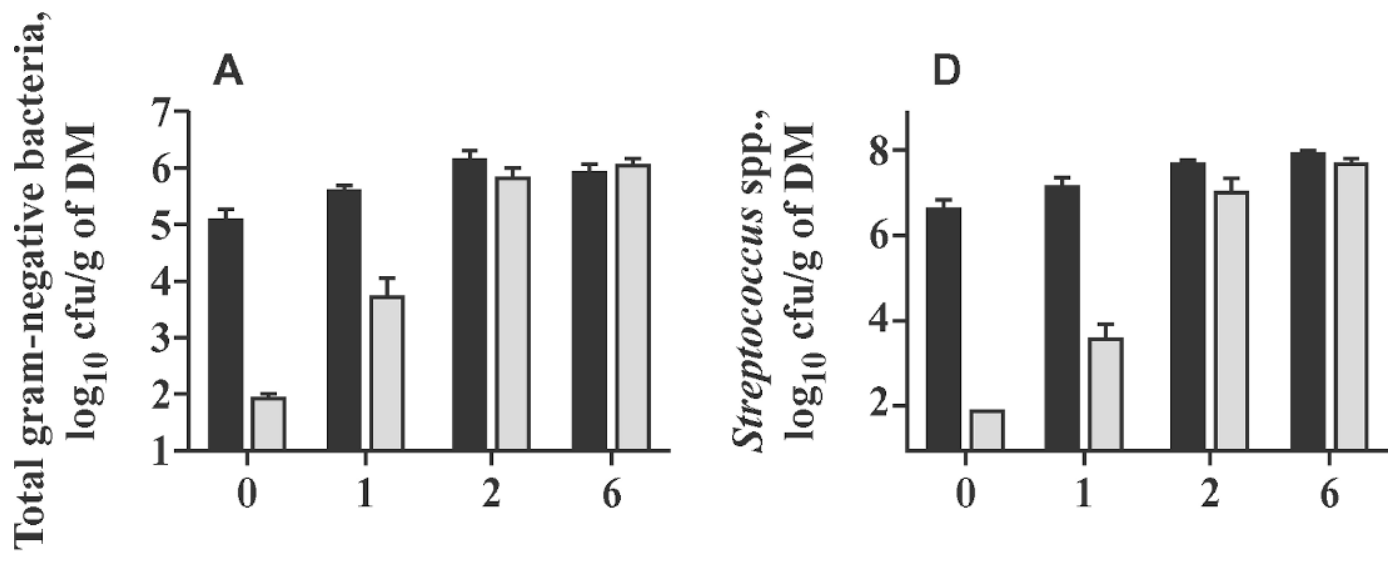

B
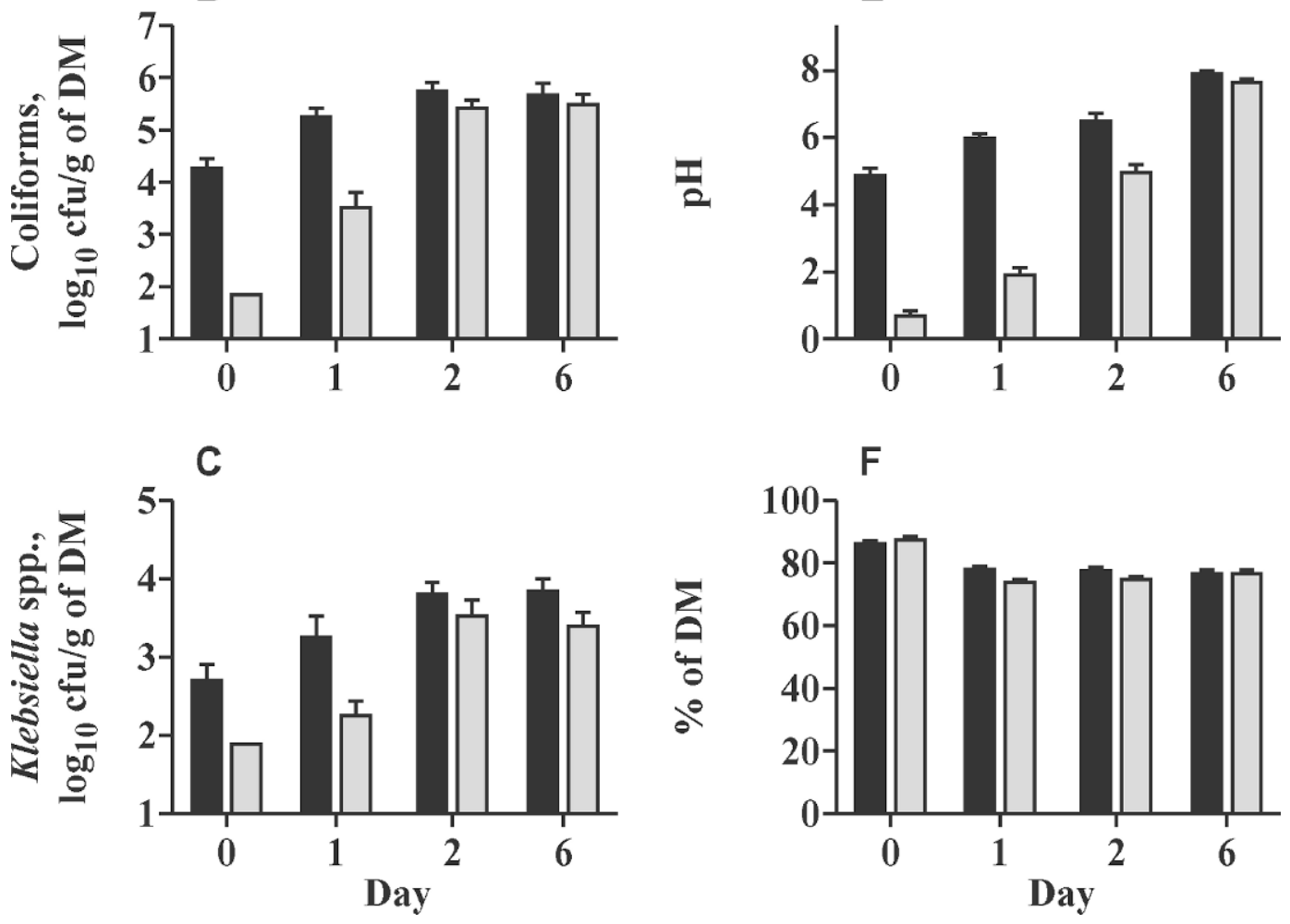

Figure 1. Counts of gram-negative bacteria (A), coliforms (B), Klebsiella spp. (C), and Streptococcus spp. (D); pH (E); and percentage of DM (F) in untreated sawdust and sawdust treated with an acidic conditioner on d 0,1, 2, and 6 after use as bedding in free stalls.

of the bacterial counts measured in recycled manure differed between conditioner-treated and untreated bedding on $\mathrm{d} 2$ and 6 . Recycled manure treated with conditioner had a lower $\mathrm{pH}$ on $\mathrm{d} 0,1$, and 2 compared with untreated bedding. On d 0 , the DM content of bedding treated with conditioner was higher than that of untreated recycled manure. Treatment with condi- tioner did not affect the DM content of recycled manure on $\mathrm{d} 1,2$, and $6(P<0.05)$.

\section{DISCUSSION}

The organic material treated with conditioner had reduced bacterial counts before being used as bedding. 


\section{Control}

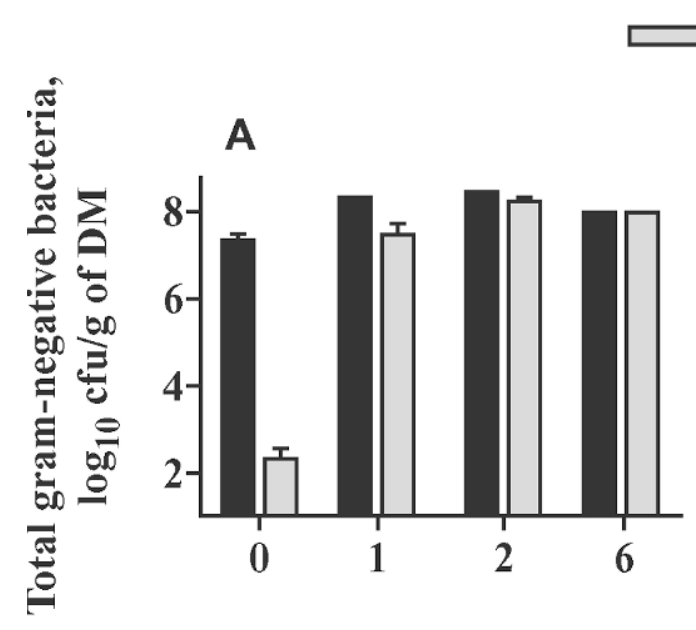

Treatment

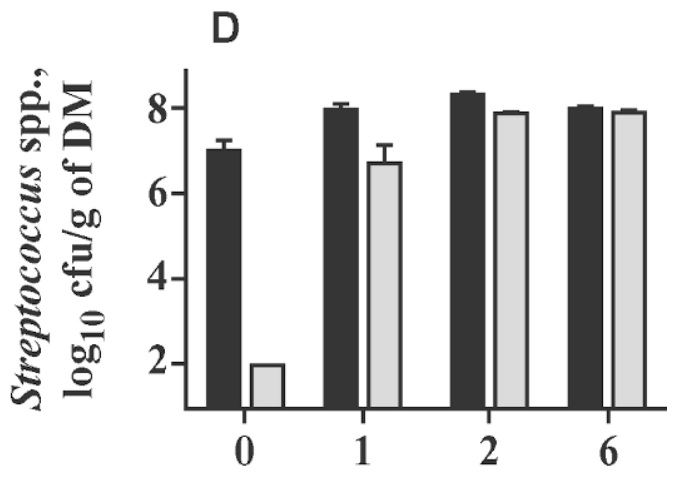

B
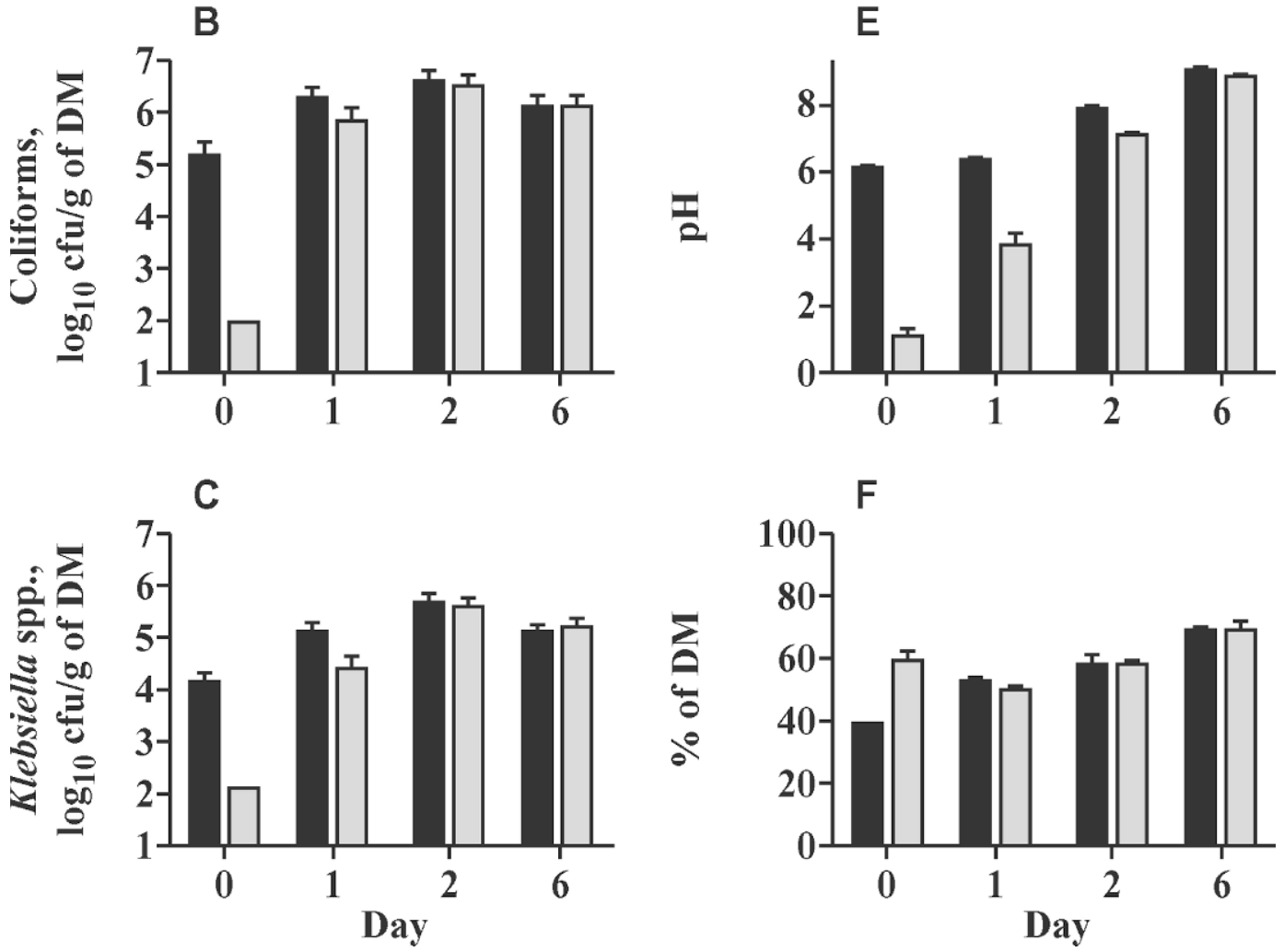

Figure 2. Counts of gram-negative bacteria (A), coliforms (B), Klebsiella spp. (C), and Streptococcus spp. (D); pH (E); and percentage of DM $(\mathrm{F})$ in untreated recycled manure solids and recycled manure solids treated with an acidic conditioner on $\mathrm{d} 0$, 1,2 , and 6 after use as bedding in free stalls.

However, in organic materials the antibacterial effects of the conditioner were no longer present after $1 \mathrm{~d}$ of use as bedding in free stalls. The antimicrobial effects of the conditioner were more persistent in sawdust than in recycled manure. Each bacterial population measured in this trial was reduced in sawdust for $1 \mathrm{~d}$. In comparison, coliform and Klebsiella spp. counts were reduced in recycled manure only before use as bedding. The relative difference between bedding types in the effectiveness of the conditioner in reducing bacterial populations was related to the $\mathrm{pH}$ of the sawdust and recycled manure. The $\mathrm{pH}$ of untreated sawdust before use as bedding was acidic compared with the nearly neutral $\mathrm{pH}$ of recycled manure. Previous trials indi- 
cated an interaction between the $\mathrm{pH}$ of bedding and the antibacterial activity of both alkaline and acidic conditioners (Hogan et al., 1999). The results of the current trial concurred with previous data. Corresponding to the increase in bacterial numbers in both organic materials was a comparable increase in bedding $\mathrm{pH}$ during each 7 -d period before bedding was replaced in the stalls.

The use of organic bedding materials in free stalls can provide a source of teat end exposure to common mastitis pathogens. Management practices attempting to reduce bacterial exposure are often arduous and unsuccessful (Hogan and Smith, 1997). The use of conditioners has historically provided a reduction in mastitis pathogens in bedding for a relatively short time. The combination of bedding being contaminated with manure as cows entered the free stalls, removal of bedding and conditioner as cows exited the free stalls, and buffering of the conditioner by the bedding seemed to result in reduced bacterial counts for only 24 to $48 \mathrm{~h}$ after treating the organic bedding with an acidic conditioner. The acidic conditioner tested in the current study may need to be applied daily or every other day to control mastitis pathogens in free-stall organic bedding.

\section{ACKNOWLEDGMENTS}

Salaries and research support were provided by state and federal funds appropriated to the Ohio Agricultural Research and Development Center, The Ohio State University. Manuscript Number 32-06 AS.

\section{REFERENCES}

Fairchild, T. P., B. J. Arthur, J. H. Moore, and W. E. Hylton. 1982. Coliform counts in various bedding materials. J. Dairy Sci. 65:1029-1035.

Hogan, J. S., V. L. Bogacz, L. M. Thompson, S. Romig, P. S. Schoenberger, W. P. Weiss, and K. L. Smith. 1999. Bacterial counts associated with sawdust and recycled manure bedding treated with commercial conditioners. J. Dairy Sci. 82:1690-1695.

Hogan, J. S., and K. L. Smith. 1997. Bacterial counts in sawdust bedding. J. Dairy Sci. 80:1600-1605.

Hogan, J. S., K. L. Smith, K. H. Hoblet, D. A. Todhunter, P. S. Schoenberger, W. D. Hueston, D. E. Pritchard, G. L. Bowman, L. E. Heider, B. L. Brockett, and H. R. Conrad. 1989. Bacterial counts in bedding materials used on nine commercial dairies. J. Dairy Sci. 72:250-258.

Rendos, J. J., R. J. Eberhart, and E. M. Kesler. 1975. Microbial populations of teat ends of dairy cows, and bedding materials. J. Dairy Sci. 58:1492-1500.

SAS Institute. 2003. SAS User's Guide: Statistics, Version 9 ed. SAS Inst., Inc., Cary, NC.

Ward, W. R., J. W. Hughes, W. B. Faull, P. J. Cripps, J. P. Sutherland, and J. E. Sutherst. 2002. Observational study of temperature, moisture, $\mathrm{pH}$, and bacteria in straw bedding, and faecal consistency, cleanliness and mastitis in cows in four dairy herds. Vet. Rec. 151:199-206. 